\title{
Enzymatic efficiency of plant and microbial phytase in cereal-rapeseed diets for growing pigs
}

\author{
D. Weremko, H. Fandrejewski, St. Raj and G. Skiba
}

\author{
The Kielanowski Institute of Animal Physiology and Nutrition, \\ Polish Academy of Sciences \\ 05-110 Jablonna, Poland
}

(Reccived 27 Junc 2001; accepted 6 November 2001)

\begin{abstract}
The experiment was carried out on 24 growing Polish Landrace pigs. The apparent digestibility of $P$ from cereal grains (maize, barley, wheat, triticale, rye or mixture of barley with rye) and from diets containing cereals and $25 \%$ rapeseed meal (RSM) or $40 \%$ soyabean meal (SBM) was determined. The diets were unsupplemented or supplemented with microbial phytase $(1000 \mathrm{FTU} / \mathrm{kg})$. The digestibility of $\mathrm{P}$ was measured by an indirect method (with $\mathrm{Cr}_{2} \mathrm{O}_{3}$ as an indicator) in 129 individual collections.

The activity of intrinsic phytase in maize and oil meals was low (no more than $180 \mathrm{FTU} / \mathrm{kg} \mathrm{DM}$ ) and was considerably higher in other cereals (from $750 \mathrm{FTU}$ in barley to $2077 \mathrm{FTU} / \mathrm{kg} \mathrm{DM}$ in rye). The apparent digestibility of $\mathrm{P}$ in bariey, wheat, triticale and rye did not differ between species (average $37.1 \%$ ) and was about $17 \%$ percentage points higher $(\mathrm{P}<0.01)$ than in maize.

Although it was estimated that the effect of intrinsic and microbial phytase on digestibility of $P$ was additive, plant phytase was 32 and $41 \%$ less effective than microbial phytase in diets with RSM and SBM, respectively. The intrinsic phytase content in cereal improved $P$ digestibility in diets with RSM or SBM by $9.3-9.6 \%$ per 1000 FTU. Supplementation of diets with microbial phytase (1000 FTU) increased P digestibility by 13.7 and $16.3 \%$ in RSM and SBM diets, respectively. However, the increase in the content of digestible P by microbial phytase was similar (about $1 \mathrm{~g} / \mathrm{kg}$ ) in dicts with both protein sources.
\end{abstract}

KEY WORDS: intrinsic phytase, microbial phytase, phosphorus digestibility, pigs

\section{INTRODUCTION}

Digestibility of phytate phosphorus can be improved by supplementation of feeds with microbial phytase (Näsi at al., 1995; Jongbloed et al., 1996) or by for- 
mulation of diets with components containing a high activity of native phytase (Helander et al., 1994; Han et al., 1997). The effect of microbial phytase supplementation in diets with a high intrinsic phytase content on phosphorus digestibility in pigs is almost unknown in literature. Moreover, available studies are discrepant about the efficiency of both types of phytase in diets for pigs. Eeckhout and De Paepe (1996) found that in a maize-soyabean meal dict microbial phytase was $74 \%$ more efficient than wheat phytase. In contrast, Han et al. (1997) reported a higher efficiency of cereal phytase originating from wheat bran in improving phytate $P$ utilization by pigs than microbial phytase.

The major protein source in pig feeds is soyabean meal (SBM). Rapeseed meal (RSM) is also a high-protein feed that may successfully replace SBM. Both of these oilmeals contain considerable amounts of phosphorus. However, the rapeseed meal contains about 2 times as much total phosphorus than soyabean meal and a higher proportion of phytate $\mathrm{P}$ in total phosphorus than SBM (78 vs 64\%; Rodehutscord et al., 1997). Also, the localization of phytate in seeds differs between both species (Tombs, 1967; Mills and Chong, 1977). These differences in distribution of phytate P may influence the susceptibility of phytates to hydrolysis by phytase. For this reason the efficiency of phytase treatment could be different in both protein feeds, which was obscrved in vitro by Żyła and Koreleski (1993).

Literature on the availability of RSM phytate phosphorus to pigs is scarce, in contrast with information on SBM.

The presented experiment was conducted to determine the relative efficiency of phytases (plant and microbial) when added to diets with a high phytate phosphorus content containing RSM or SBM.

\section{MATERIAL AND METHODS}

\section{Animals and experimental procedure}

The study was conducted on 24 castrated male pigs (Polish Landrace), initially weighing approximately $35 \mathrm{~kg}$. The animals were housed a thermo-neutral environment in metabolic cages with free access to water via nipple waterers.

The apparent digestibility of $P$ from diets containing individual cereals (maize, barley, wheat, triticale, rye or mixture of barley with rye in a proportion of $2: 1$ ) as the only tested component or cereals with RSM or SBM was investigated. The tested diets contained $25 \%$ of RSM and $40 \%$ of SBM to achieve at least $50 \%$ of total $\mathrm{P}$ coming from these feeds according to procedure described by Jongbloed and Kemme (1990a). All cereal grains used in the study except maize were obtained from local farms and were not dried in order to avoid the negative effects of thermal processing on intrinsic phytase activity. Maize was obtained from the 
market. In order to accurately determine the effect of native phytase on $\mathrm{P}$ digestibility of diets, the batches of cereals differing in the content of phytate $\mathrm{P}$ and intrinsic phytase were tested. Three different low glucosinolate rapeseed meals were also used. The diets were unsupplemented or supplemented with microbial phytase (1000 FTU/kg, ALLZYME - Alltech, Inc. Biotechnology). All of the tested diets were supplemented with vitamins and cssential trace elements according to the Nutrient Requirements of Pigs (1993), but no inorganic P was added. The $\mathrm{Ca} / \mathrm{P}$-total ratio in the diets was maintained at $1.3: 1$ by addition of limestone. The diets were not pelleted.

The feed was offered twice daily, at 8.00 and $14.00 \mathrm{~h}$. Just before feeding, water was added to diets at a proportion of $1: 1$. Daily rations were calculated as $4 \%$ liveweight of animals.

\section{Digestibility determination}

The digestibility of $\mathrm{P}$ was measured by an indirect method, $0.2 \%$ chromic oxide was included in the experimental diets as an indicator. A total of 129 individual collections were made. Faeces were collected for 5 days following 9 days of an adaptation period.

During each collection period, fresh total faeces were collected twice daily from cach pig. After the end of each collection period, representative samples from each pig were ground to pass through a $2.5 \mathrm{~mm}$ sieve and analysed.

\section{Analytical procedures}

Phosphorous content in feeds and faeces samples was determined photometrically using the vanado-molybdate method. Ca was determined from ash solutions by atomic absorption spectrophotometry. Chromic oxide was analysed using the method described by Fenton and Fenton (1979). Phytase activity of feeds was measured according to Eeckhout and Paepe (1994), one unit (FTU) of phytase activity being defined as the activity liberating $1 \mu \mathrm{mol}$ of inorganic phosphate per min from $0.0015 \mathrm{~mol}$ of sodium phytate at $37^{\circ} \mathrm{C}$ and $\mathrm{pH} 5.5$. P-phytate was determined by the method of Tangkongchitr et al. (1981) modified by Antonicwicz ct al. (1992).

\section{Statistical analysis}

In order to determine the separate influences of plant and microbial phytase on $P$ digestibility, a statistical analysis model of multiple regression was used according to ANOVA, Statgralics, Version 7.0 (1993). 


\section{RESULTS AND DISCUSSION}

The phosphorus fractions and phytase content in feedstuffs is presented in Table 1 . The content of total phosphorus in rapeseed meal averaged $13.8 \mathrm{~g} / \mathrm{kg}$ dry matter, while in soyabean meal it was $6.6 \mathrm{~g} / \mathrm{kg}$ DM. The cereals contained similar amounts of phosphorus, which ranged from $3.30 \mathrm{~g} / \mathrm{kg} \mathrm{DM}$ in maize to $4.78 \mathrm{~g} / \mathrm{kg}$ DM in barley. These results are in agreement with the data found in literature (Jongbloed and Kemme, 1990a; Eeckhout and Paepe, 1994; Rodehutscord et al., 1997).

The proportion of phytate $\mathrm{P}$ in total $\mathrm{P}$ depended on the type of feedstuff. In cereal grains the proportion of phytate $\mathrm{P}$ was higher (from 60 to $84 \%$ ) than in oil seeds (on average $63 \%$ ). The greatest proportion of phytate $\mathrm{P}$ was found in maize and wheat ( 84 and $77 \%$, respectively). The above results do not differ from those cited by other authors (Eeckhout and Paepe, 1994; Rodehutscord et al., 1997).

The phytase content in feedstuffs varied markedly. Phytase activity in rye was highest among cereals (2077 FTU/kg DM). The activity of phytase in maize and

TABLE I

Content of total phosphorus $(P)$, phytate phosphorus $\left(P_{f}\right)$, phytase and calcium $(\mathrm{Ca})$ in rapesecd meal, soyabean meal and cereals grain, $\mathrm{g} / \mathrm{kg} \mathrm{DM}$

\begin{tabular}{|c|c|c|c|c|c|c|}
\hline Fcedstuffs & Batch & $P, g$ & $P_{p}, g$ & $\mathrm{P} / \mathrm{P}, \%$ & Phytase, FTU & $\mathrm{Ca}, \mathrm{g}$ \\
\hline \multirow[t]{4}{*}{ Rapeseed meal } & 1 & 14.53 & 9.06 & 62.8 & 26 & 8.59 \\
\hline & 2 & 13.68 & 7.90 & 57.7 & 18 & 7.12 \\
\hline & 3 & 13.04 & 9.19 & 70.5 & 12 & 7.46 \\
\hline & rage & 13.75 & 8.72 & 63.7 & 19 & 7.72 \\
\hline Soyabean meal & & 6.58 & 4.11 & 62.1 & 184 & 4.97 \\
\hline \multirow[t]{3}{*}{ Maize } & 1 & 3.90 & 3.01 & 77.1 & 67 & 0.35 \\
\hline & 2 & 3.33 & 2.78 & 83.6 & 161 & 0.32 \\
\hline & rage & 3.62 & 2.90 & 80.4 & 114 & 0.34 \\
\hline \multirow[t]{3}{*}{ Barley } & 1 & 4.78 & 3.26 & 68.3 & 750 & 0.86 \\
\hline & 2 & 4.46 & 2.68 & 60.0 & 1198 & 0.41 \\
\hline & rage & 4.62 & 2.97 & 64.2 & 974 & 0.64 \\
\hline \multirow[t]{3}{*}{ Wheat } & 1 & 4.18 & 3.21 & 76.7 & 1043 & 0.40 \\
\hline & 2 & 3.58 & 2.22 & 62.1 & 1794 & 0.40 \\
\hline & rage & 3.88 & 2.72 & 69.4 & 1419 & 0.40 \\
\hline Triticalc & & 4.26 & 3.10 & 72.7 & 1591 & 0.45 \\
\hline Rye & & 4.03 & 2.62 & 65.0 & 2077 & 0.60 \\
\hline
\end{tabular}


both oilmeals was considerably lower than in cereals. The wheat and barley phytase content was in agreement with other data (Berk and Schulz, 1993; Eeckhout and Paepe, 1994). The phytase concent in rye was 2-3 times lower than in the investigation of Eeckhout and Paepe (1994).

The concentration of calcium, similarly as the phosphorus content, was higher in RSM than in cereals, which contained below $0.9 \mathrm{~g} \mathrm{Ca} / \mathrm{kg}$ dry matter.

The apparent digestibility of phosphorus from cereal grains is presented in Table 2. The digestibility of $\mathrm{P}$ was the lowest in maize 18.2 and $21.4 \%$, and the highest was in triticale, $40.4 \%$. In the remaining cereals, the apparent digestibility of $\mathrm{P}$ did not differ between species (36-40\%) and was significantly higher than in maize. This can be attributed to the presence of naturally occurring phytase in the seed coat. Apparent $P$ digestibility coefficients for maize and barley are similar to those obtained by Jongbloed and Kemme (1990a), Wecke et al. (1994) and for wheat by Jongbloed and Kemme (1990a), Berk and Schulz (1993) and BarrierGuillot et al. (1996). According to Düngelhoef et al. (1994) and Rodehutscord et al. (1996) the digestibility of wheat phosphorus was higher $(62-68 \%)$ than obtained in our study. In contrast, the digestibility of $\mathrm{P}$ determined in triticale was about $8 \%$ lower than cited in the literature (Berk and Schulz, 1993; Düngelhoef et al., 1994). No data was found about digestibility of $P$ in rye grain.

TABLE 2

Apparent digestibility of phosphorus $(x \pm S E)$ in the ration with cereal grains not supplemented with microbial phytase

\begin{tabular}{lcccc}
\hline Cereal & $\mathrm{n}$ & $\begin{array}{c}\text { Intrinsic phytase } \\
\text { FTU/kg DM }\end{array}$ & $\begin{array}{c}\text { Total P } \\
\text { g/kg DM }\end{array}$ & $\begin{array}{c}\text { Digestibility } \\
\text { of P, \% }\end{array}$ \\
\hline Maize 1 & 6 & 66 & 3.82 & $18.20 \pm 1.11$ \\
Maize 2 & 4 & 158 & 3.26 & $21.40 \pm 0.76$ \\
Barley 1 & 4 & 735 & 4.68 & $37.07 \pm 1.37$ \\
Barley 2 & 4 & 1174 & 4.37 & $35.80 \pm 1.77$ \\
Wheat 1 & 5 & 1022 & 4.10 & $37.52 \pm 1.37$ \\
Wheat 2 & 4 & 1758 & 3.51 & $35.75 \pm 2.45$ \\
Triticale & 4 & 1559 & 4.18 & $40.37 \pm 2.28$ \\
Rye & 4 & 2036 & 3.95 & $36.42 \pm 2.50$ \\
Barley + rye 2:1 & 4 & 1196 & 3.90 & $34.55 \pm 1.71$ \\
\hline
\end{tabular}

In the three batches of rapeseed meals used, the proportion of phytate $\mathrm{P}$ in total phosphorus varied from 57.7 to $70.5 \%$ and the content of nonphytate $P$ was from 3.85 to $5.78 \mathrm{~g} / \mathrm{kg}$ (Table 1). Its effect on digestibility of total $\mathrm{P}$ in rapeseed meal was determined by analysis of variance based on 18 results obtained for each batch of rapeseed with the same cereals (Table 3 ). The P digestibility of feed with RSM 3 containing the least nonphytate $\mathrm{P}(0.385 \%)$ was significantly lower than that with 
TABLE 3

Effect of nonphytate $P$ content in rapeseed meal (threc batches) on phosphorus digestibility in cerealrapeseed diets

\begin{tabular}{lcccc}
\hline \multicolumn{1}{c}{ Indices } & \multicolumn{3}{c}{ SEM } \\
\hline Rapeseed meal, batch & 2 & 1 & 3 & \\
Nonphytatc $\mathrm{P}$ in RSM, g/kg & 5.78 & 5.47 & 3.85 & \\
P digestibility, \% & $31.68^{\mathrm{a}}$ & $30.70^{\mathrm{a}}$ & $27.41^{\mathrm{h}}$ & 0.389 \\
\hline
\end{tabular}

the higher nonphytate $\mathrm{P}$ fraction content $(0.55$ and $0.58 \%)$. The absolute differences among extreme values were $4.3 \%$ and suggested that the variability range of the digestibility coefficient of total $\mathrm{P}$ between individual batches of rapeseed meal may reach even $6-8 \%$. Similar variability of $P$ digestibility of rapeseed meal was shown by other authors (Yong-Gang Liu et al., 1995).

The digestibility coefficients of P in the mixtures of RSM or SBM with cereals other than maize were $10-17 \%$ or $10-14 \%$ points higher then determined in RSMmaize or SBM-maize diet, respectively (Tables 4 and 5). These differences were probably due to the activity of intrinsic phytase present in these cereals but not in maize. In mixtures of RSM with cereals, $P$ digestibility was in agreement with this found by Pointillart et al. (1985), Näsi et al. (1995) and for SBM by Helander et al. (1994) and Jongbloed et al. (1996). The lower P digestibility of mixtures based on maize corresponds to the lowest phytase content in this grain. Therefore, it could be said that the phytase activity of specific cereal grains has a significant influence on the P digestibility of the whole diet. It another study, Jongbloed and Kemme (1990b) showed that pelleting of the maize-wheat-soyabean meal diet resulted in reduction of intrinsic phytase activity by $500 \mathrm{FTU} / \mathrm{kg}$ and consequently decreased the digestibility of $\mathrm{P}$ by 18 percentage points.

Microbial phytase added to cereal-SBM diets improved the digestibility of $P$ from 14.7 in the diet with barley to $33.9 \%$ points in the diet with maize (Table 4 ).

TABLE 4 Apparent digestibility of phosphorus $(x \pm S E)$ in diets with soyabcan meal (SBM) without and with microbial phytase

\begin{tabular}{lccccc}
\hline Diets & $\mathrm{n}$ & $\begin{array}{c}\text { Intrinsic phytasc } \\
\text { FTU/kg DM }\end{array}$ & $\begin{array}{c}\text { Microbial phytase } \\
\text { FTU/kg DM }\end{array}$ & $\begin{array}{c}\text { Total P } \\
\text { g/kg DM }\end{array}$ & $\begin{array}{c}\text { Digestibility } \\
\text { of P, \% }\end{array}$ \\
\hline SBM + maize & 4 & 183 & - & 4.90 & $22.36 \pm 1.46$ \\
SBM + maize & 4 & 183 & 1000 & 4.90 & $56.31 \pm 1.81$ \\
SBM + barley & 4 & 768 & - & 5.22 & $32.17 \pm 1.36$ \\
SBM + barley & 4 & 768 & 1000 & 5.22 & $46.90 \pm 2.43$ \\
SBM + wheat & 4 & 1114 & - & 4.71 & $36.61 \pm 1.86$ \\
SBM + wheat & 4 & 1114 & 1000 & 4.71 & $54.50 \pm 3.85$ \\
\hline
\end{tabular}


TABLE 5

Apparent digestibility of phosphorus $(\mathrm{x} \pm \mathrm{SE}$ ) in diets with rapeseed meal (RSM) without and with microbial phytase

\begin{tabular}{lccccc}
\hline Dicts & $\mathrm{n}$ & $\begin{array}{c}\text { Intrinsic phytase } \\
\text { FTU/kg DM }\end{array}$ & $\begin{array}{c}\text { Microbial phytase } \\
\text { FTU/kg DM }\end{array}$ & $\begin{array}{c}\text { Total P } \\
\text { g/kg DM }\end{array}$ & $\begin{array}{c}\text { Digestibility } \\
\text { of P, \% }\end{array}$ \\
\hline RSM + maize & 10 & 53 & - & 6.37 & $18.54 \pm 0.98$ \\
RSM + maize & 4 & 53 & 1000 & 6.37 & $27.70 \pm 0.58$ \\
RSM + barley & 6 & 552 & - & 7.01 & $35.42 \pm 1.08$ \\
RSM + barley & 4 & 552 & 1000 & 7.01 & $50.10 \pm 3.29$ \\
RSM + wheat & 6 & 766 & - & 6.58 & $35.04 \pm 1.50$ \\
RSM + wheat & 4 & 766 & 1000 & 6.58 & $46.03 \pm 1.22$ \\
RSM + triticale & 6 & 1166 & - & 6.64 & $31.53 \pm 0.47$ \\
RSM + triticalc & 4 & 1166 & 1000 & 6.64 & $47.83 \pm 3.51$ \\
RSM + rye & 8 & 1521 & - & 5.44 & $29.11 \pm 1.37$ \\
RSM + rye & 4 & 1521 & 1000 & 5.44 & $44.18 \pm 2.75$ \\
RSM + barley + rye & 6 & 809 & - & 5.73 & $29.07 \pm 0.90$ \\
RSM + barlcy + ryc & 4 & 809 & 1000 & 5.73 & $48.37 \pm 1.35$ \\
\hline
\end{tabular}

The enzyme-supplemented diets containing RSM significantly increased P digestibility on average by $15.1 \%$ points (Table 5 ). The greatest increase of $\mathrm{P}$ digestibility of $19.3 \%$ points was found in barley with rye mixture, while the lowest was found for RSM-maize diet, $9.2 \%$ points. The increase of phosphorus digestibility in the mixtures of RSM or SBM with barley was similar (about $14.7 \%$ points; Tables 4 and 5). Pigs fed the SBM-wheat diets supplemented with microbial phytase digested $\mathrm{P}$ by 8.5 percentage points better than those fed the RSM-wheat diet ( $54.5 \mathrm{vs} 46.0 \%$ ). A relatively small response to added enzyme was found on RSM-maize diet $(9.2 \%$ points). In contrast, if maize was used as the basal diet with SBM, the increase of $P$ digestibility was 3 times higher and amounted to 33.9 percentage points. The small response to phytase added to the RSM-maize diet is consistent with the results of Näsi et al. (1995) and differences in this response among RSM or SBM-maize diets may probably be explained by differences in the amount of phytase units per gram phytate $P$ of diets (224 vs 354 , respectively) and needs further investigation. RSM contains a higher proportion of phytate $\mathrm{P}$ in total phosphorus than SBM (78 vs 64\%; Rodehutscord et al., 1997). Also, phytate localization in the seeds of both species differs. Eighty percent of phytate phosphorus in rape seed (Mills and Chong, 1977) is distributed throughout the cotyledons and the rest is in the seed coat; its is also concentrated in substructures within protein bodies (globoids). In contrast to rape seed, soyabeans appear to have no definite site of phytate P localization (Tombs, 1967). The differences in distribution of phytate $P$ in rapeseed and soyabean may influence the susceptibility of phytates to hydrolysis by phytase. For this reason the efficiency of phytase treatment could be different in both protein feeds. 
Although the average effect of microbial phytase supplementation on increasing P digestibility coefficients in RSM and SBM diets differed (15.1 and 21.8\% points, respectively), the increase of the digestible P content was similar ( 0.95 and $1.08 \mathrm{~g} / \mathrm{kg}$, respectively). The same amount $(1000 \mathrm{FTU} / \mathrm{kg})$ of microbial phytase added to different diets increased the digestible $P$ content in a wide range from 0.45 to $1.0 \mathrm{~g}$ (Cromwell et al., 1995; Näsi at al., 1995; Jongbloed et al., 1996). On the other hand, it should be remembered that the efficiency of phytate hydrolysis by phytase is dependent on the amount of phytate $\mathrm{P}$ in combination with other factors such as the form and location of phytic acid salts within the ingredients used in the mixture (Maenz, 2001).

In order to accurately mathematically compare the influence of intrinsic and microbial phytase on the digestibility of $P$, multiple regression was used in the statistical analysis. The dependent variable was the level of apparent digestibility (DIG, \%) of P in feedstuffs, whereas the independent variables were the content of intrinsic phytase in diets $\left(\mathrm{FTU}_{\mathrm{i}}\right.$ ) and amount of added microbial phytase (FIT ${ }_{\mathrm{m}}$ ), both phytases expressed in $1000 \mathrm{FTU} / \mathrm{kg}$ feedstuff. Two databases were created for dicts containing rapeseed meals and soyabean meal. Both of these sets included the respective single cereals. The following equations were obtained:

for diets with SBM

$\mathrm{DIG}=23.8( \pm 1.46)+9.6( \pm 1.42) \mathrm{FITi}+16.3( \pm 0.02) \mathrm{FITm} \quad(\mathrm{n}=63)$

$\mathrm{R}^{2}=0.71 \quad \mathrm{SE}=6.1$

for dicts with RSM

$\mathrm{DIG}=22.9( \pm 1.19)+9.3( \pm 1.12) \mathrm{FITi}+13.7( \pm 1.19)$ FITm $\quad(\mathrm{n}=115)$

$\mathrm{R}^{2}=0.63 \quad \mathrm{SE}=6.4$

In the equations, values of independent variables represent the part of the digestibility cocfficient that can be attributed to intrinsic or microbial phytase, respectively. From these equations it appears that plant phytase improved P digestibility in diets with SBM or RSM by 9.6-9.3\% per 1000 FTU. Supplementation of diets with microbial phytase (1000 FTU $/ \mathrm{kg}$ ) increased P digestibility by 16.3 and $13.7 \%$ in SBM and RSM diets, respectively. The equations obtained in our study have shown that the effect of both types of phytase is additive; this is in agreement with the observations of Düngelhoef et al. (1994). However plant phytase was 32 and $41 \%$ less effective than microbial phytase in diets with RSM and SBM, respectively. Our result is in agreement with Eeckhout and Pacpe (1996) on pigs and with the observations of Frapin and Nys (1995) on broilers, but differ from the result obtained by Han et al. (1997) on pigs. These last authors showed that wheat phytase was more effective in improving plant phosphorus utilization for performance and $\mathrm{P}$ retention in the pig body than microbial phytase, but not for bone mineralization. Their results may indicate that the addition of microbial phytase in 
our experiments was too high to show the complete efficiency of this enzyme. The differences in enzyme efficiency were duc to different physico-chemical properties of these phytases. Phytase of plant origin hydrolyses the phosphate group at the $\mathrm{C}_{3}$ position first, whereas phytase of microbial origin acts first at the $\mathrm{C}_{6}$ position (Kies, 1996). Environmental conditions determine the optimal activity of phytases (Dvorakova, 1998). The optimum of plant phytase activity (6-phytase) appears at temperatures between $45-55^{\circ} \mathrm{C}$ and at a $\mathrm{pH}$ of about 5 (Kies, 1996; Nys et al., 1996), while microbial phytase has optimum at $55-65^{\circ} \mathrm{C}$ and two $\mathrm{pH}$ optima: one at $\mathrm{pH} 2.5$ and the other at $\mathrm{pH} 5.5$. For these reasons plant phytase is less active in a pig's stomach than microbial phytase. Results from several experiments with pigs have shown that dietary phytase activity was predominantly active in the stomach. (Kemme at al., 1998). In pigs, phytase ability to hydrolyse phytate $\mathrm{P}$ was generally very low or was not observed in the lower small intestine because of the basic pH (6.5-7.6) there (van der Meulen and Bakker, 1991), which is less favourable for phytase activity, or because proteolytic enzymes in the small intestine may degrade phytase.

The somewhat higher intercept value obtained in the equation with SBM points to the better digestibility of $\mathrm{P}$ in soyabean than rapeseed meal and is in agreement with other data cited in the review by Weremko et al. (1997). The differences in $P$ digestibility increase by microbial phytase (1000 FTU) in diets with rapeseed $(13.7 \%)$ and with soyabean meal $(16.3 \%)$ may be explained by the different $\mathrm{pH}$ values for optimal phytate P breakdown in RSM and SBM diets. Żyła and Koreleski (1993) showed that decreasing the $\mathrm{pH}$ to 3.0 caused a rise in the amount of inorganic phosphorus released by phytase, while increasing it to 5.5 resulted in substantial reduction of $P$ release. In contrast to rapeseed, soyabean meal was dephosphorylated more efficiently at $\mathrm{pH} 4.5$ than at pH 2.6 (Żyła ct al., 1989). The level of phytase activity and extent of phytate hydrolysis in the digestive tract may well be limited by gastric retention time (Kemme et al., 1998). In vitro, the amount of inorganic phosphorus released from rapeseed meal reached a maximum level of total phosphorus after $4 \mathrm{~h}$ of the reaction, whereas for soyabean meal it took $3 \mathrm{~h}$ (Żyła and Koreleski, 1993).

\section{CONCLUSIONS}

The results of this study indicate that in pigs, plant phytase was 32 and $41 \%$ less effective per 1000 units activity than microbial phytase in diets with rapeseed meal and soyabean meal, respectively, and that the effect of both types of phytase is additive. It may be claimed that supplementing microbial phytase to diets with a high plant phytase content can substantially increase the digestibility of plant phosphorus. 


\section{REFERENCES}

Antoniewicz A., Dumańska K., Ombach A., 1992. Availability of fosforus from field bean (Vicia $f a b a)$ and lupin (Lupinus albus) seeds to broiler chickens. J. Anim. Feed Sci. I, 127-137

Barrier-Guillot B., Casado P., Maupetit P., Jondreville C., Gatel F., 1996. Wheat phosphorus availability: !-In vitro study; factors affecting endogenous phytasic activity and phytic phosphorus content. J. Sci. Food Agr. 70, 62-68

Berk A., Schulz E., 1993. Die Verdaulichkeit des Phosphorus aus unterschicdlichen Futtermitteln beim Schwein während der Mast. In: Kongressband, VDLUFA-Kongresses: Qualität und Hygiene von Lebensmittcln in Produktion und Verarbeitung, Scluriftenreihe 37, pp. 309-312

Cromwell G.L., Coffey R.D., Parker G.R., Monegue H.J., Randolph J.H., 1995. Efficacy of recombinant-derived phytase in improving the bioavailability of phosphorus in corn-soybean meal diets for pigs. J. Anim. Sci. 73, 2000-2008

Düngelhocf M., Rodelutscord M., Spickers II., Pfeffer E., 1994. Effects of supplemental microbial phytase on availabitity of phosphorus contained in maize, wheat and triticale to pigs. Anim. Feed Sci. Tech. 49, !-10

Dvorakova J., 1998. Phytase: sources, preparation and exploitation. Folia Microbiol. 43, 323-338

Eeckhout W., De Paepe M., 1994. Total phosphorus, plytate-phosphorus and phytase activity in plant feedstuffs. Anim. Feed Sci. Tech. 47, 19-29

Eeckhout W., De Paepe M., 1996. In vitro and in vivo comparison of microbial and plant phytase. In: M.B. Coclho, E.T. Kornegay (Editors). Phytase in Animal Nutrition and Waste Management. BASF Corporation, pp. 237-240

Fenton T.W., Fenton M., 1979. An improved procedure for the determination of chromic oxide in feed and facces. Can. J. Anim. Sci. 59, 631-634

Frapin D., Nys Y., 1995. Relative efficiency of microbial and vegetal phytases and additional effect on phosphorus availability in broilers. In: Procecdings of World's Poultry Science Association, 10-th European Symposium on Poultry Nutrition, Antalya (Turkey), pp. 352-354

Han Y.M., Yang F., Zhou A.G., Miller E.R., Ku P.K., Hogberg M.G., Lei X.G., 1997. Supplemental phytases of microbial and cereal sources improve dietary phytate phosphorus utilization by pigs from weaning through finishing. J. Anim. Sci. 75, 1017-1025

Helander E., Näsi M., Partanen K., 1994. Inclusion of wheat bran in barley-soybean meal diets with different phosphorus levels for growing-finishing pigs I. Effects on nutrient digestibility and mineral balances in finishing pigs. J. Agr. Sci. Finland 3, 27-39

Jongbloed A.W., Kemme P.A., 1990a. Apparent digestible phosphorus in the feeding of pigs in relation to availability, requirement and environment. 1. Digestible phosphorus in fecdstuffs from plant and animal origin. Neth. J. Agr. Sci. 38, 567-575

Jongbloed A.W., Kemme P.A., 1990b. Effect of pelleting mixed feeds on phytase activity and the apparent absorbability of phosphorus and calcium in pigs. Neth. J. Agr. Sci. 38, 567-575

Jongbloed A.W., Kemme P.A., Mroz Z., 1996. Effectiveness of Natuphos phytase in improving the bioavailabilities of phosphorus and other nutrients for growing-finishing pigs. In: M.B. Coelho, E.T. Kornegay (Editors). Phytase in Animal Nutrition and Waste Management. BASF Corporation, pp. 259-274

Kemme P.A., Jongbloed A.W., Mroz Z., Beynen A.C., 1998. Diurnal variation in degradation of plytic acid by plant phytase in the pig stomach. Livest. Prod. Sci. 54, 33-44

Kies K., 1996. Phytase - mode of action. In: M.B. Coelho, E.T. Kornegay (Editors). Phytase in Animal Nutrition and Waste Management. BASF Corporation, pp. 205-212 
Macnz D.D., 2001. Enzymatic characteristics of phytases as they relate to their use in animal feeds. In: M.R. Bedford, G.G. Partridge (Editors). Enzymes in Farm Animal Nutrition. (CCAB International, pp. 61-84

Meulen J. van der., Bakker J.G.M., 1991. Effect of various sources of dietary tibre on chemicophysical characteristics of digesta in the stomach and the small intestine of the pig. In: Proccedings of $\mathrm{V}^{\text {th }}$ International Symposium on Digestive Physiology in the Pig, Wageningen (The Netherland). EAAP-Publication No 54, pp. 440-445

Mills J.T., Chong J., 1977. Ultrastructure and mineral distribution in heat-damaged rapeseed. Can. J. Plant Sci. 57, 21-30

Näsi J.M., Helander E.H., Partanen K.H., 1995. Availability for growing pigs of mincrals and protein of a high phytate barley-rapeseed meal diet treated with Aspergillus niger phytase or soaked with whey. Anim. Feed Sci. Tech. 56, 83-98

Nutrient Requirements of Pigs. Nutritive Value of Feeds (in Polish), 1993. The Kielanowski Institute of Animal Plyysiology and Nutrition (Editor). Jablonna (Poland)

Nys Y., Frapin D., Pointillart A., 1996. Occurence of phytase in plants, animals and microorganisms. In: M.B. Coclho, E.T. Kornegay (Editors). Phytase in Animal Nutrition and Waste Management. BASF Corporation, pp. 213-236

Pointillart A., Fontaine N., Thomasset M., Jay M.E., 1985. Phosphorus utilization, intestinal phosphatases and hormonal control of calcium metabolism in pigs fed phytic phosphorus: soyabean or rapeseed diets. Nutr. Rep. Int. 32, 155-167

Rodelutscord M., Faust M., Lorenz H., 1996. Digestibility of phosphorus contained in soybean meal, barley, and different varietics of wheat, without and with supplemental phytase fed to pigs and additivity of digestibility in a wheat-soybean-meal diet. J. Anim. Physiol. Anim. Nutr. 75, $40-48$

Rodehutscord M., Faust M., Hof Ch., 1997. Digestibility of phosphorus in protein-rich ingredients for pig diets. Arch. Anim. Nutr. 50, 201-211

Statgraphics Plus Version 7.0 for DOS, 1993. Statistical Graphics System by Graphics Corporation Tangkongchitr U., Seib P.A., Hoseney R.C., 1981. Phytic acid. I. Determination of three form of phosphorus in flour, dough and bread. Cereal Chem. 58, 226-228

Tombs M.P., 1967. Protein bodies of the soybean. Plant Physiol. 42, 797-803

Wecke C., Reinisch F., Liebert F., Köhler R., 1994. Absorption and utilization of phosphorus in maize and soybean meal by piglets with respect to phytase supplementation. In: Proceedings of $\mathrm{VI}^{\text {th }}$ International Symposium on Digestive Physiology in Pigs. Bad Doberan (Germany). EAAPPublication No 80, Vol. I1, pp.339-341

Weremko D., Fandrejewski H., Żebrowska T., Han In K., Kim J.H., Cho W.T., 1997. Bioavailability of phosphorus in feeds of plant origin for pigs - review. Asian-Austr. J. Anim. Sci. 10, 55I-566

Yong-Gang Liu., Smits B., Steg A., Jongbloed R., Jensen S.K., Eggum B.O., 1995. Crambe meal: digestibility in pigs and rats in comparison with rapeseed meal. Anim. Feed Sci. Tech. 52, $257-270$

Żła K., Koreleski J., Kujawski M., 1989. Dephosphorylation of phytate compounds by means of acid phosphatase from Aspergillus niger. J. Sci. Food Agr. 49, 315-324

Żyla K., Koreleski J., 1993. In-vitro and in-vivo dephosphorylation of rapesecd meal by means of phytate-degrading enzymes derived from Aspergillus niger. J. Sci. Food Agr. 61, 1-6 


\section{STRESZCZENIE}

Enzymatyczna efektywność fitazy roślinnej i mikrobiologicznej w dietach zbożowo-rzepakowych dla rosnących świń

Doświadczenie przeprowadzono na 24 rosnących świniach rasy polskiej białej zwisłouchej. Oznaczono strawność pozorną fosforu w kukurydzy, jęczmieniu, pszenicy, pszenżycie, życie, mieszance jęczmienia z żytem oraz w dietach zawierających te zboźa i $25 \%$ śruty rzepakowej lub $40 \%$ śruty sojowej. Do badań użyto diety bez lub z dodatkiem fitazy mikrobiologicznej (w ilości 1000 jednostek/kg). Strawność P oznaczono metodą wskaźnikową $\left(\mathrm{z} \mathrm{Cr}_{2} \mathrm{O}_{3}\right)$ w 129 indywidualnych kolekcjach.

Aktywność fitazy własnej kukurydzy i śrut poekstrakcyjnych była niska (nie więcej niż l 80 FTU $i$ kg s.m.). W pozostałych zbożach była ona istotnie wyższa, od $750 \mathrm{FTU}$ w jęczmieniu do 2077 FTU/kg s.m. w życie. Strawność pozorna P jęczmienia, pszenicy, pszenżyta i źyta nie różniła się istotnie między gatunkami (średnio $37.1 \%$ ) j była o około 17 jednostek procentowych wyższa $(\mathrm{P}<0.01)$ niz kukurydzy.

Stwierdzono, że wpływ obydwóch typów fitazy na strawność fosforu był addytywny. Fitaza roślinna w dictach z RSM i SBM była jednak odpowiednio o 32 i $42 \%$ mniej efektywna niż fitaza mikrobiologiczna. Fitaza natywna zawarta w zbożach zwiçkszała strawność P w dietach z RSM hub SBM o 9.3-9.6\% na 1000 FTU. Dodatek do diety fitazy mikrobiologicznej (1000 FTU) zwiększał strawność P o 13.7 i $16.3 \%$, odpowiednio w diecie rzepakowej i sojowcj. Wzrost zawartości P strawnego był jednak podobny (około $1 \mathrm{~g} / \mathrm{kg}$ ) w obydwóch dietach (z RSM i z SBM). 